IRA-International Journal of Management \& Social Sciences

ISSN 2455-2267; Vol.14, Issue 02 (February, 2019)

Pg. no. 47-59.

Institute of Research Advances

http://research-advances.org/index.php/RAJMSS

\title{
Indian Press Coverage of Farmers' Suicides in Andhra Pradesh: A Content Analysis
}

\author{
Dr. J. Madhu Babu ${ }^{1 \#} \&$ S. Raja Rao ${ }^{2}$ \\ ${ }^{1}$ Assistant Professor, Dept. of Journalism and Mass Communication, Acharya Nagarjuna \\ University, Guntur, Andhra Pradesh, India. \\ ${ }^{2}$ Research Scholar, Dept. of Journalism and Mass Communication, Acharya Nagarjuna \\ University, Guntur, Andhra Pradesh, India.
}

\# corresponding author

Type of Work: Peer Reviewed.

DOl: http://dx.doi.org/10.21013/jmss.v14.n2.p3

\section{How to cite this paper:}

Babu, J.M., Rao, S.R. (2019). Indian Press Coverage of Farmers' Suicides in Andhra Pradesh: A Content Analysis. IRA-International Journal of Management \& Social Sciences (ISSN 2455-2267), 14(2), 47-59. doi:http://dx.doi.org/10.21013/jmss.v14.n2.p3

(C) Institute of Research Advances.

\section{(cc) BY-NC}

This work is licensed under a Creative Commons Attribution-Non Commercial 4.0 International License subject to a proper citation to the publication source of the work.

Disclaimer: The scholarly papers as reviewed and published by the Institute of Research Advances (IRA) are the views and opinions of their respective authors and are not the views or opinions of the IRA. The IRA disclaims of any harm or loss caused due to the published content to any party.

Institute of Research Advances is an institutional publisher member of Publishers International Linking Association Inc. (PILA-CrossRef), USA. The institute is an institutional signatory to the Budapest Open Access Initiative. Hungary advocating the open access of scientific and scholarly knowledge. The Institute is a registered content provider under Open Access Initiative Protocol for Metadata Harvesting (OAI-PMH).

The journal is indexed \& included in WorldCat Discovery Service (USA), CrossRef Metadata Search (USA), WorldCat (USA), OCLC (USA), Open J-Gate (India), EZB (Germany) Scilit (Switzerland), Airiti (China), Bielefeld Academic Search Engine (BASE) of Bielefeld University, Germany, PKP Index of Simon Fraser University, Canada. 
IRA-International Journal of Management छ' Social Sciences

\begin{abstract}
India, consisting of 16 percent of world population subsists only on 2.4 percent land resources. Agriculture is the only source of livelihood to the two third of the population which gives employment to 57 percent of the workforce. Agriculture in India is often regarded as gambling with monsoons, because of its almost exclusive dependency on precipitation from monsoons. The failure of monsoons leading to a series of droughts, lack of better prices, exploitation by middlemen, and Gene Modified (GM) seed companies who are selling expensive cotton seeds and fertilizers, all of which have led to a series of suicides committed by farmers across India. Farmers' suicides are a complex phenomenon. Since the 1990s farmer suicides in India have made headlines. The journalist Palagummi Sainath highlighted that 17,500 farmers were suicides between 2002 to 2006. The government figures show 14,000 farmers took their own lives in 2011. The total number of farmers' suicides crossed 3 lakh mark till in 2014. That most suicides occurred in the states of Andhra Pradesh, Maharashtra, Karnataka, Kerala and Punjab. This study seeks to investigate news items on farmers' suicides in the Indian newspapers. A quantitative content analysis was adopted in this research. This study used two English dailies i.e. The Hindu and The New Indian Express and two Telugu dailies i.e. Eenadu and Andhrajyothi were taken for analysis. It is not a random sample. In this, a purposive sample method was adopted. The selection time period was one year i.e. from January 1, 2015, to December 31, 2015. Keeping in view ten subject categories have been mainly identified for this research. All the data collected were analyzed simple percentage and mean, standard deviation, ANOVA, Chi-square have been used for analysis.
\end{abstract}

Keywords: Farmers suicides, Newspapers, News coverage.

\title{
1.Introduction
}

The Indian agriculture sector has faced a serious crisis since the 1990s. According to it, the most affected places are Vidharbha (Maharashtra), Warangal (Telangana), Rayalaseema, (Andhra Pradesh), Northern Karnataka (Karnataka) Wayanad (Kerala), Chhattisgarh etc. The rural indebtedness is the major problem behind the farmer suicides. Policies associated with the process of liberalization increased stress on the country's peasantry, with the withdrawal formal support towards this sector, which in turn made farmers dependent on non-institutional sources such as private moneylenders and private agents. Seed sector liberalization has not only brought private players in agriculture but also encouraged monoculture of hybrid cash crops requiring costly inputs, which eventually gets transformed into debt. This situation coupled with crop failure due to pest attack, climatic change and lack of irrigation mismatched to the expectation of the farmers which led to indebtedness. Agonized farmers found a solution to those families in the forbidden path of committing suicide.

\subsection{Farmer Suicides: Statistical Data}

India experienced its first wave of farmer suicides in 1997, at which time the number of farmer suicides per year was around 14,000. This number increased in 2005 to 17,000 per year (Sainath, 2007). Statistics reveal that farmer suicides in India account for $11.2 \%$ of all the suicides. Over a period of 10 years, from 2005 to 2015, the farmer suicide rate in the country has ranged between 1.4 and 1.8 per 100,000 total population. The year 2004 saw the highest number of farmer suicides in India. As many as 18,241 farmers committed suicide during this year.

In 2010, the National Crime Records Bureau of India reported a total of 135, 599 suicides in the country out of which 15,963 were farmer suicides. In 2011, a total of 135,585 suicide cases were reported in the country out of which 14,207 were farmers. $11.2 \%$ of the total suicide cases in the year 2012 were farmers - a quarter of which were from the state of Maharashtra. In 2014, there were 5,650 farmer suicide cases. The farmer suicide rate is higher in the states of Maharashtra, Pondicherry, and Kerala.

\subsection{The view of the media}

Media is the fourth estate of democracy. It has the power of cultivating an image, creating the opinion and casting the behaviour. Media in India are very powerful and had reached grass root level people. Media brings changes to society. They bring new values into the system. All over the world, it is observed that individuals and villages that welcomed modern media have more modern attitudes are more progressive, and moved to modern roles faster than those who did not (Pool,1966). Farmer suicides have received relatively little attention in the media in recent decades as most corporate media outlets tend to focus on issues that attract more viewers and readers such as fashion and pop culture.

P.Sainath said that a lecture was given at Pondicherry University about agricultural distress and farmer suicides in India "Media-houses sent hundreds of reporters and photographers to cover a popular fashion event in Mumbai, not a single one was sent to Vidarbha just a few miles away, where hundreds of farmers had taken their lives". The 
reduced government involvement in the agricultural sector and rising inequality due to tax lift given to multinational corporate companies as the main reason behind the farmer suicides.

\subsection{Media Perception of Farmers 'Suicides}

The media are now a big business, with a concentration of ownership in corporate hands growing by the day. The fundamental feature of the media in our times is the growing disconnect between mass media on the one hand and compromised media on the other hand. So our reporting of rural matters and Agriculture issues is very poor and superficial. The management of the newspapers has not been able to create a cadre journalist who had both human empathy as well as professional competence for agricultural and rural reporting. Both the media houses and the journalists should have concern for farmers and the poor.

The media particularly the Telugu language press was reporting farmers' suicides in a much more systematic manner than before. Some Telugu papers listed the number of suicides in their district additions. Media observers pointed out that the coverage by the Telugu media much better when compared to earlier rounds of farmer deaths. In fact, observers noted that even the Telugu dailies published from state reported the deaths in a more systematic fashion than in the past. However, media critics also noted that there had been no attempts either by the English language press or the local media to collate and analyze the information at a broader level to highlight the issue at stake (Sridhar. 2006).

\subsection{Farmers' Suicides in International Level}

Farmers' suicides are a worldwide crisis of smallholder farming. Small family farms are getting wiped out across the planet and it has been happening for the last 20-30 years. It is just that this has been very intense in India in the last 15 years. Otherwise, the farm suicides have caused major concern in Korea, Nepal and Sri Lanka have high rates of farm suicides. In Africa, Burkina Faso, Mali etc., have had high rates of farmers' suicides as the cotton product gets wiped out by the US and EU subsidies. Incidentally, suicides rates among farmers in the United States, Midwest and other regions have also been extremely high from time to time. In fact, in the eighties, suicides rates amongst farmers in Oklahoma, for instance, were more than twice the National suicide rates from men in the United States and it is rare that suicides are higher than urban (Sainath P. 2009).

\section{Review of Literature}

\subsection{Studies on Farmers' Suicide}

The study conducted in Austria proved that the media guidelines have had an impact on the quality of reporting as well as on suicidal behaviour in Austria, and stress the importance of collaborating with nationwide but also with reasonable media to achieve efficacy. Media guidelines for reporting on suicides are a widely used means of preventing initiative suicides (Niederkrotenthalera, T. \& Sonneck, G, 2007). The continues exposer to a particular method of suicide leads to an increase in that kind of suicide rate. The suicide reports are increasing day by day. The study conducted in Austria revealed that there is considerable evidence of an association between method availability and method-specific suicide rate. There is also evidence that restriction of method availability is often associated with a reduction in the method of specific suicides rates. There is some evidence that restriction on method availability under certain conditions may reduce overall suicides rates (Cantor, C.H. \& Baume, P.J.M. 1998).

Mc. Namara, Sanchez and Echavarria as cited by Shore (1980) found that content of mass media did not do good to peasants of Columbia, as it met more the need of the large farmers. Cordera found that newspapers in Costa Rica ignored information on agriculture although it was the main activity of the country. Solomon, as cited by Jeffers (1997), argued that media transit, not mere content, but content with shape and structure.

Quantitative research on farmers' suicides in India comprises, similar to studies on suicides in general, mostly methods such as the calculation of suicide rates or similar statistics (Mishra 2007, 2014), verbal autopsy (Behere and Behere 2008), econometric calculations (Hebous and Klonner 2014), So far, factors like indebtedness (Jeromi, 2007), globalization (Shiva 2004), liberalization of the economy (Nagaraj 2008) have been cited as the major reasons for farmer suicides in India. 
Mishra $(2007,2014)$ calculated suicide rates per 1, 00,000 people as well as trends in suicide rates for male farmers and non-farmers in the period of 1995 to 2012. In order to compute these rates and to adjust them according to age, he used data provided by the NCRB as well as the Census of India.

Another quantitative approach, namely verbal autopsy, was applied by Behere and Behere (2008) in one district of Maharashtra. The main aims of their research were to identify the causes of suicides as well as to elaborate intervention strategies. Hence, a survey consisting of more than 50 questions was carried out in the period of one year (2005 to 2006). Behere and Behere (2008) interviewed relatives of farmers and landowners who committed suicide during this time.

An econometric analysis of farmers' suicides in India is provided by Hebous and Klonner(2014). Their study was motivated by their perception of farmers' suicides as an expression of personal misery. As a result, they focused on economic distress among farmers by empirically analyzing the relationship between risk, agricultural change and farmers' suicides. Their study concentrates on two Indian states, Maharashtra and Karnataka, over a period of seven years (1998 to 2004). Hebous and Klonner (2014) incorporated suicide statistics from police records, householdlevel data from the National Sample Survey (NSS) as well as meteorological parameters and land use statistics. The combination of all these data aimed at identifying the effects of economic shocks and changes in agricultural patterns as well as the parameters of farmers' suicides.

Concerning the geographic distribution of suicides, Mohanty et al. (2007) and Patel et al. (2012) found that most suicides occur in rural areas. This is attributed to higher availability of pesticides and a greater lack of medical services in rural areas (Patel et al. 2012; Radhakrishnan and Andrade 2012). Similarly and with respect to the method of suicide, almost all studies assent to poisoning as well as hanging as most frequent means (Balayannis and Cook 2015; CHRGJ 2011; Mohanty et al. 2007; Patel et al. 2012; Radhakrishnan and Andrade 2012).

Shiva (2004) has linked the occurrence of farmer suicides with the opening up of the seed sector to global corporations in India. She argues that the change in the input economy of agricultural production along with the loss of farmers' right to save the seed for next season has put the farmer into a spiralling debt cycle, which is causing them to commit suicide.

\subsection{Significance of the Study}

The topic of farmer suicide is significant on multi-levels: on the political, social, economic and public health levels. It is important to understand what aggravates the farmers' plight in order to decide on legitimate government policy that will reduce the frequency of suicides. It is the media's responsibility. In this research, we provide a comprehensive review of evidence on farmers' suicides. Taking into account information from published news items.

\section{Methodology}

\subsection{Research Objectives}

1. To study the differences in frequency and space devoted to the farmers' suicides to form of Presentation, level, placement of coverage.

2. To analyze the direction of treatment given by the sample dailies to farmers' suicides.

3. To compare this research study results to previous research reviews.

\subsection{Research Area}

Andhra Pradesh, state of India located in the South Eastern part of the subcontinent. It is bounded by the Indian states of Tamil Nadu to the South, Karnataka, to the South West and West, Telangana to the North West and North, and Odisha to the North East. The Eastern boundary is a $970 \mathrm{KM}$ coastline along the Bay of Bengal. Telangana was a region with Andhra Pradesh for all most six decades, but in 2014 it was carved off to form a separate state. It is a primarily agricultural state. The state was divided into three regions i.e. Uttar Andhra contains Srikakulam, Vizianagaram and Visakhapatnam districts. Coastal Andhra it contains East Godavari, West Godavari, Krishna, Guntur, Prakasam and Nellore districts. Rayalaseema contains Chittoor, Kadapa, Kurnool and Anantapur districts.

\subsection{Research Method}

Data for the study were gathered through a content analysis of four newspapers. Content analysis is defined as "a method of studying and analyzing communication in a systematic, objective and quantitative manner to measure 
variables" (Kerlinger, 1973, p.525) as coated in (Riffe, Lacy \& Fico, 2008, p.24). The data for the study were news items published by four newspapers; The Hindu, The New Indian Express, Eenadu and Andhrajyothi published in Andhra Pradesh.

\subsection{Profiles of Selected Newspapers}

\section{The Hindu}

The Hindu started in 1878 as a weekly, become a daily in 1889 and from then on has been steadily growing to the circulation of 15,58,379 copies (ABC: July - December 2012) and readership of about 22.58 Lakhs. It is printed in 21 centers. The editor of the newspaper is Mukund Padmanabhan. It is published by Kasturi and sons.

\section{The New Indian Express}

The New Indian Express is the oldest English daily an undisputed credibility for the last 80 years. The New Indian Express from 25 centers in Tamil Nadu, Karnataka, Andhra Pradesh, Kerala and Odisha. The company is owned and managed by Manoj Kumar Sonthalia. The editorial director of the group is Prabhu Chawla.

\section{Eenadu}

Eenadu is an Indian Telugu language daily newspaper which is the largest circulated Telugu newspaper. It is published from 23 centers. The chief editor of the paper is Ch. Ramoji Rao on January 25, 1989. Eenadu introduced the district supplement known as 'Mini edition'.

\section{Andhrajyothi}

Andhrajyothi is a Telugu daily newspaper published in the Indian state of Andhra Pradesh and Telangana. KLN Prasad started the Andhrajyothi newspaper in 1960. Presently it is edited by K.Srinivas. Vemuri Radhakrishna is its managing director. It is published from 18 centers.

The prime consideration in the selection of these newspapers was the prominence as reflected in their circulation and their regional representation.

\subsection{Sampling Procedure}

The universe for this study comprises all the editions of the four selected dailies published during the calendar year January 1, 2015, to December 31, 2015. This study was based on the complete census during 12 months period- not a random sample. From a preliminary analysis, it was concluded that a small sample of issues would result in an unfair representation of farmer suicides related news coverage. Throughout the year, news of farmer suicides is distributed in various propositions. If a random sample were taken, the risk of missing important instances of farmer suicides coverage would be high. Therefore, hundreds of newspaper issues had been sampled. The leading English daily The Hindu and the leading regional language Telugu daily Eenadu were taken as a base daily newspaper (Madhu Babu.J, 2010). Two steps were adopted to select the editions (dates) to constitute the study.

First step: The researcher identified 144 farmer suicides for the study period.

Second step: The researchers examining the follow-up news.

\subsection{Form of Presentation}

The form of presentation for the study consisted of news, news stories, photos, cartoons, editorials, articles, columns, editorial cartoons and letters -to -the editor published in the four selected dailies.

\subsection{Level of Coverage}

All news items were analysed in terms of the level of coverage - regional and national.

Regional: the news items that contained farmer suicides incidents or happenings are concerning all districts of Andhra Pradesh state.

National: news that happened around the country excluding Andhra Pradesh was also treated as National level.

\subsection{Placement of Coverage}

It refers to the location of different items on newspapers and measured under the following heads.

1. Front page, 2. Inside pages, 3. Editorial page.

\subsection{Operational Definitions of Subject Categories}

The news items were then exclusively put in 10 different subject categories that included. 
1. Government: it was a news item that mention the Central and State Government statements and announcements regarding farmer suicides.

2. Political Parties: a news item criticizing by opposition parties on suicides.

3. Administration: a news item that mentioned the financial assistance by administrators.

4. Police: the maintenance of law and order for all citizens.

5. The agony of farmers' families: news mentioned the agony of farmers' family members and relatives.

6. Human Rights: a news item mentioned violating human rights.

7. Protests by farmer associations: news that mentioned protests by farmer associations

8. Banks: news that mentioned providing the loans to farmers.

9. Media: it was a story that mentions suicides of farmers initiate by media its own.

10. Others: issues that did not fall in any category.

\subsection{Directional Analysis}

The purpose of using the directional analysis is to find out how the newspapers have accorded treatment to farmer suicides related news items in their coverage of the themes. A three-point scale was adopted.

1. Favourable, 2. Un-favorable, 3. Neutral.

The method of the coefficient of imbalance was issued to establish the direction given to farmer suicides in the news items.

\subsection{Procedure of Measurement}

A form of presentation (Unit analysis) coded into various subject categories, were measured both in terms of their frequencies and space. When a photograph accompanied news items, the space of the photograph was also treated as part of the news item. News space was measured by column centimetres.

\subsection{Statistical Techniques Used}

For analyzing the data the following statistical measures have been used. Simple percentage, mean, standard deviation (SD), ANOVA (F test) and chi-square test of association.

\section{Results and Discussion}

\subsection{News Coverage}

The content of The Hindu, The New Indian Express, Eenadu and Andhrajyothi for the period of one year (January 1, 2015, to December 31, 2015) was analyzed for finding out the quantitative and total space covered by farmer suicides issues. When analyzing the total number of items and total space covered by farmer suicides issues it was found that Eenadu was leading as far as the number of items (243) and space covered 4686 col.cms., by farmer issues concerned. Whereas the coverage of Andhrajyothi was not so far, it has covered 222 items and $4584 \mathrm{col} . \mathrm{cms}$ of space to farmer suicides issues followed by the Hindu has covered 158 items and 3821 col.cms space and The New Indian Express 50 news items and space 1405 col.cms.(see table -1).

Table 1. Percentage distribution of frequencies and space in selected dailies

\begin{tabular}{|l|l|l|l|l|}
\hline Name of the newspaper & fr & $\%$ & sp & $\%$ \\
\hline The Hindu & 158 & 23.5 & 3821 & 26.4 \\
\hline The New Indian Express & 50 & 7.5 & 1405 & 9.7 \\
\hline Eenadu & 243 & 36.1 & 4686 & 32.3 \\
\hline Andhra Jyothi & 222 & 32.9 & 4584 & 31.6 \\
\hline Total & 673 & 100.0 & 14496 & 100.0 \\
\hline
\end{tabular}

\subsection{Analysis of Forms of News}

Table -2 analyzes the form of presentation. A form of presentation is one of the key indicators of the significance attached to any item by the newspaper. It was measured under the following heads. The presentation in table -7 reveals that in case of Eenadu, majority of the items of farmer suicides issues were published in the form of 'news' (123 items), followed by 'photos' (94) less used form of presentation were 'news stories' (14), 'cartoons' and 'columns' were each four items. During the study period, it was found that Eenadu has published the highest 
number of photos (94) followed by Andhrajyothi (84), The Hindu (47) and The New Indian Express (13). The two English newspapers have not given a single cartoon on farmer suicides issues.

Table 2. Distribution of frequencies and space with form presentation by selected dailies

\begin{tabular}{|c|c|c|c|c|c|c|c|c|c|c|}
\hline \multirow[t]{2}{*}{ Form of Presentation } & \multicolumn{2}{|c|}{ The Hindu } & \multicolumn{2}{|c|}{$\begin{array}{c}\text { The New Indian } \\
\text { Express }\end{array}$} & \multicolumn{2}{|c|}{ Eenadu } & \multicolumn{2}{|c|}{ Andhra Jyothi } & \multicolumn{2}{|c|}{ Total } \\
\hline & fr & $\mathrm{sp}$ & fr & $\mathrm{sp}$ & $\mathrm{Fr}$ & $\mathrm{sp}$ & fr & $\mathrm{sp}$ & fr & $\mathrm{sp}$ \\
\hline News & 93 & 2960 & 31 & 1249 & 123 & 3082 & 99 & 2993 & 346 & 10284 \\
\hline News Stories & 11 & 617 & 1 & 22 & 14 & 670 & 16 & 614 & 42 & 1923 \\
\hline Photos & 47 & - & 13 & - & 94 & - & 85 & - & 239 & - \\
\hline Cartoons & - & - & - & - & 4 & - & 6 & - & 10 & - \\
\hline Editorials & 1 & 48 & - & - & 3 & 276 & 1 & 12 & 5 & 336 \\
\hline Articles & 1 & 44 & 1 & 108 & - & - & 4 & 448 & 6 & 600 \\
\hline Columns & 3 & 133 & - & - & 4 & 644 & 5 & 445 & 12 & 1232 \\
\hline Editorial Cartoons & - & - & - & - & - & - & - & - & - & - \\
\hline Letters-to-the-editor & 2 & 19 & 4 & 26 & 1 & 14 & 6 & 62 & 13 & 121 \\
\hline Total & 158 & 3821 & 50 & 1405 & 243 & 4686 & 222 & 4584 & 673 & 14496 \\
\hline
\end{tabular}

\subsection{Placement of Coverage}

It refers to the location of different items on newspapers and measured under the following heads placement of different items of farmer suicides issues were presented in table-3. The data presented in table reveals that in case of The Hindu majority of issues (16) were placed in front page followed Eenadu (12), Andhrajyothi (10) and The New Indian Express (1).

In the inside pages, Eenadu published the highest number of news items (216) have compared to the other dailies. While Andhrajyothi (189) occupied the second place followed by the Hindu (135) and the New Indian Express (42).

In the editorial page coverage, Andhrajyothi published the highest number of 23 items, followed by Eenadu 50 and the two English newspapers published every 7 items.

Table 3.Distribution of frequencies and space with the placement of coverage by selected dailies

\begin{tabular}{|c|c|c|c|c|c|c|c|c|c|c|}
\hline \multirow{3}{*}{$\begin{array}{l}\text { Placement of } \\
\text { coverage }\end{array}$} & \multicolumn{8}{|c|}{ Name of the newspaper } & \multirow{2}{*}{\multicolumn{2}{|c|}{ Total }} \\
\hline & \multicolumn{2}{|c|}{ The Hindu } & \multicolumn{2}{|c|}{$\begin{array}{c}\text { The New Indian } \\
\text { Express }\end{array}$} & \multicolumn{2}{|c|}{ Eenadu } & \multicolumn{2}{|c|}{$\begin{array}{c}\text { Andhra } \\
\text { Jyothi }\end{array}$} & & \\
\hline & fr & $\mathrm{sp}$ & fr & $\mathrm{sp}$ & fr & $\mathrm{sp}$ & fr & $\mathrm{sp}$ & $\mathrm{fr}$ & $\mathrm{sp}$ \\
\hline Front page & 16 & 238 & 1 & 8 & 12 & 232 & 10 & 114 & 39 & 592 \\
\hline Inside pages & 135 & 3339 & 42 & 1263 & 216 & 3520 & 189 & 3493 & 582 & 11615 \\
\hline Editorial page & 7 & 244 & 7 & 134 & 15 & 934 & 23 & 977 & 52 & 2289 \\
\hline total & 158 & 3821 & 50 & 1405 & 243 & 4686 & 222 & 4584 & 673 & 14496 \\
\hline
\end{tabular}

\subsection{Level of Coverage}

It refers to reporting of farmer suicides at various levels. Coverage level was measured in the following manner. The data presented in table-4 reveals that items of farmer suicides issues showed different levels of coverage in four newspapers in case of Eenadu maximum coverage from regional (180 items), followed by Andhrajyothi (119 items ), The Hindu(63 items ) and the New Indian Express (17 items). In national coverage, Andhrajyothi ranked $1^{\text {st }}$ place with 103 items, followed by the Hindu (95 items), Eenadu (63 items) and the New Indian Express (33 items). 
IRA-International Journal of Management E゚ Social Sciences

Table 4.Distribution of frequencies and space with a level of coverage by selected dailies

\begin{tabular}{|c|c|c|c|c|c|c|c|c|c|c|}
\hline \multirow{3}{*}{$\begin{array}{l}\text { Level of } \\
\text { Coverage }\end{array}$} & \multicolumn{8}{|c|}{ Name of the newspaper } & \multirow{2}{*}{\multicolumn{2}{|c|}{ Total }} \\
\hline & \multicolumn{2}{|c|}{ The Hindu } & \multicolumn{2}{|c|}{$\begin{array}{c}\text { The New Indian } \\
\text { Express }\end{array}$} & \multicolumn{2}{|c|}{ Eenadu } & \multicolumn{2}{|c|}{ Andhra Jyothi } & & \\
\hline & $\mathrm{fr}$ & $\mathrm{sp}$ & $\mathrm{fr}$ & $\mathrm{sp}$ & fr & $\mathrm{sp}$ & fr & $\mathrm{sp}$ & fr & $\mathrm{sp}$ \\
\hline Regional & 63 & 1603 & 17 & 438 & 180 & 2703 & 119 & 1770 & 379 & 6514 \\
\hline National & 95 & 2218 & 33 & 967 & 63 & 1983 & 103 & 2814 & 294 & 7982 \\
\hline Total & 158 & 3821 & 50 & 1405 & 243 & 4686 & 222 & 4584 & 673 & 14496 \\
\hline
\end{tabular}

\subsection{Analysis of Subject Categories}

Table -5 shows data about the coverage of news under 10 different subject categories. As can be seen, in the three newspapers the subject category 'media' ranked $1^{\text {st }}$ in terms of frequency and coverage of space i.e. Andhrajyothi (163 items, 3435 col.cms) followed by Eenadu (141 items, 2846 col.cms). The subject category 'Government' received the highest coverage in terms of frequency and space in the Hindu (46 items, 1177col.cms). The other three newspapers Eenadu, Andhrajyothi and the New Indian Express gave second place to the subject category 'Government'. The subject category 'agony of farmers/ families' and 'protest by farmers associations' received 13 items, 11 items respectively in The Hindu. The Telugu newspaper Eenadu reported only 16 items on 'agony of farmers'. As regards the allocation of space to the 'agony of farmers/families' The Hindu dominated the other three newspapers giving space $222 \mathrm{col}$. cms. Coming to the 'human rights' subject category Eenadu dominated the other three newspapers by giving 13 items to the subject.

Table 5. Distribution of frequencies and space with subject categories by selected dailies

\begin{tabular}{|c|c|c|c|c|c|c|c|c|c|c|}
\hline \multirow{3}{*}{ Subject categories } & \multicolumn{8}{|c|}{ Name of the newspaper } & \multirow{2}{*}{\multicolumn{2}{|c|}{ Total }} \\
\hline & \multicolumn{2}{|c|}{ The Hindu } & \multicolumn{2}{|c|}{$\begin{array}{l}\text { The New } \\
\text { Indian } \\
\text { Express }\end{array}$} & \multicolumn{2}{|c|}{ Eenadu } & \multicolumn{2}{|c|}{ Andhra Jyothi } & & \\
\hline & fr & $\mathrm{sp}$ & $\mathrm{fr}$ & $\mathrm{sp}$ & $\mathrm{fr}$ & $\mathrm{sp}$ & fr & $\mathrm{sp}$ & $\mathrm{fr}$ & $\mathrm{sp}$ \\
\hline Governments & 46 & 1177 & 8 & 213 & 32 & 778 & 29 & 532 & 115 & 2700 \\
\hline Political parties & 35 & 650 & 11 & 292 & 29 & 466 & 15 & 293 & 90 & 1701 \\
\hline Administration & - & - & - & - & - & - & - & - & - & - \\
\hline Police & 6 & 115 & 4 & 125 & 3 & 52 & 3 & 92 & 16 & 384 \\
\hline Farmers/ families & 13 & 222 & 3 & 82 & 16 & 52 & 2 & 40 & 34 & 396 \\
\hline Human rights & 6 & 188 & 4 & 208 & 13 & 322 & 1 & 24 & 24 & 742 \\
\hline Protest by farmers & 11 & 369 & 2 & 72 & 7 & 152 & 8 & 168 & 28 & 761 \\
\hline Banks & - & - & 3 & 108 & 2 & 18 & - & - & 5 & 126 \\
\hline Media & 34 & 889 & 11 & 162 & 141 & 2846 & 163 & 3435 & 349 & 7332 \\
\hline Others & 7 & 211 & 4 & 143 & - & - & 1 & - & 12 & 354 \\
\hline Total & 158 & 3821 & 50 & 1405 & 243 & 4686 & 222 & 4584 & 673 & 14496 \\
\hline
\end{tabular}

\subsection{Geographical Analysis}

The present study analyzed the news coverage, in relation to the geographical area, such as regional and national. The purpose of this analysis is to know the significance assigned by the sample dailies to these ten subject themes by region.

\section{National}

Table -6 reveals the trend of the news coverage, on regional issues in terms of frequency. As it can be seen from table-6 Anhdrajyothi topped by publishing 103 national news items, followed by The Hindu (95), Eenadu (63) and The New Indian Express (33). The Hindu gave top priority to the theme 'Government' in the coverage of national news items, followed by 'Political parties' (22) and 'Media' (17). The New Indian Express published 8 news items 
each the subject theme 'Political parties' and 'Media'. Eenadu published 20 national news items to the subject theme 'Media'. The Andhrajyothi published 72 news items on national media stories on about farmer suicides.

Table 6. Distribution of frequency of geographical location by subject categories in the dailies.

\begin{tabular}{|c|c|c|c|c|c|c|c|c|}
\hline \multirow[t]{2}{*}{$\begin{array}{l}\text { Subject } \\
\text { categories }\end{array}$} & \multicolumn{2}{|c|}{ The Hindu } & \multicolumn{2}{|c|}{$\begin{array}{c}\text { The New Indian } \\
\text { Express }\end{array}$} & \multicolumn{2}{|c|}{ Eenadu } & \multicolumn{2}{|c|}{ Andhrajyothi } \\
\hline & National & Regional & National & Regional & National & Regional & National & Regional \\
\hline Government & 37 & 9 & 5 & 3 & 11 & 21 & 16 & 13 \\
\hline Political parties & 22 & 13 & 8 & 3 & 12 & 17 & 4 & 11 \\
\hline $\begin{array}{l}\text { Administration/R } \\
\text { evenue }\end{array}$ & - & - & - & - & - & - & - & - \\
\hline Police & 3 & 3 & 3 & 1 & 2 & 1 & 3 & - \\
\hline $\begin{array}{l}\text { Farmers/their } \\
\text { families }\end{array}$ & 6 & 7 & 1 & 2 & 10 & 6 & 1 & 1 \\
\hline Human Rights & 1 & 5 & 2 & 2 & 5 & 8 & 1 & - \\
\hline $\begin{array}{l}\text { Protest by } \\
\text { farmers } \\
\text { association }\end{array}$ & 5 & 6 & - & 2 & 1 & 6 & 5 & 3 \\
\hline Banks & - & - & 3 & - & 2 & - & - & - \\
\hline Media & 17 & 17 & 8 & 3 & 20 & 121 & 72 & 91 \\
\hline Others & 4 & 3 & 3 & 1 & - & - & 1 & - \\
\hline $\mathrm{n}=$ & 95 & 63 & 33 & 17 & 63 & 180 & 103 & 119 \\
\hline $\mathrm{N}=$ & \multicolumn{2}{|c|}{158} & 50 & & \multicolumn{2}{|c|}{293} & \multicolumn{2}{|c|}{222} \\
\hline
\end{tabular}

\section{Regional}

The Telugu newspaper Eenadu gave more priority to the subject category the 'Government' in the regional coverage. The theme 'political parties' received more space in Eenadu (17) followed by The Hindu (13), Andhrajyothi (11) and The New Indian Express (3). The 'Media' theme received the highest frequency (121) in the Eenadu, followed by Andhrajyothi (91), The Hindu (17) and The New Indian Express (3). The theme 'farmers and families agony' received 7 items in The Hindu followed Eenadu (6), The New Indian Express (2) and Andhrajyothi (1).

\subsection{Directional Analysis}

In the present study, an attempt was made to assess the direction of treatment given to 10 subject categories. For this purpose, a three-point scale namely favourable, unfavourable and neutral was adopted to assess the direction of the treatment of the themes. As can be seen table -7 the four sample dailies published number of unfavourable news items i.e. Eenadu (143), The Hindu (110), Andhrajyothi (99) and The New Indian Express (36). The chi-square analysis showed that the coverage given to the different issues did not differ significantly $\left(x^{2}=45.350 \mathrm{df}=11\right)$.

Between the two English dailies, The Hindu put more emphasis on the negative coverage of farmer suicides related news items ( -0.33488), throughout the study period, whereas on the two Telugu dailies Andhrajyothi gave critical treatment to the farmer suicides related news by emphasizing more on negative references $(-0.06227)$.

Although, The New Indian Express covered less number of farmer suicides related news items, the coverage of the stories was with an emphasis on negative references (-0.4464). But Eenadu also is no exception to this and was critical in covering the news items $(-0.25428)$.

Table 7.Distribution of frequencies with the direction of treatment by selected dailies

\begin{tabular}{|c|c|c|c|c|c|}
\hline \multirow[b]{2}{*}{ Name of the newspaper } & \multicolumn{4}{|c|}{ Direction of treatment } & \multirow{2}{*}{$\begin{array}{c}\text { Coefficient of } \\
\text { imbalance }\end{array}$} \\
\hline & $\mathrm{n}$ & $\mathrm{F}$ & UF & $\mathrm{Ne}$ & \\
\hline The Hindu & 158 & 34 & 110 & 14 & -0.33488 \\
\hline The New Indian Express & 50 & 5 & 36 & 9 & -0.4464 \\
\hline Eenadu & 243 & 38 & 143 & 62 & -0.25428 \\
\hline Andhrajyothi & 222 & 68 & 99 & 55 & -0.06227 \\
\hline $\mathrm{N}=$ & 673 & 145 & 388 & 140 & \\
\hline
\end{tabular}

$\mathrm{n}=$ number of news items'=favorable, $\mathrm{UF}=$ unfavorable, $\mathrm{Ne}=$ neutral. 
$x^{2}=45.350, \mathrm{df}=11$, the two-tailed $\mathrm{p}$-value is less than0.0001. By conventional criteria ,this difference is considered to be extremely statistically significant.

Table 8. One -Way ANOVA

\begin{tabular}{|l|c|c|c|c|c|}
\hline Name of the newspaper & $\mathrm{N}$ & $\sum \mathrm{X}$ & $\bar{X}$ & $\sum X^{2}$ & St. dev \\
\hline The Hindu & 8 & 158 & 19.75 & 4908 & 15.9799 \\
\hline The New Indian Express & 9 & 50 & 5.5556 & 376 & 3.504 \\
\hline Eenadu & 8 & 243 & 30.375 & 22233 & 46.0619 \\
\hline Andhrajyothi & 8 & 222 & 27.75 & 27714 & 55.4894 \\
\hline Total & & & & & \\
\hline
\end{tabular}

Table 9. F-ratio

\begin{tabular}{|c|c|c|c|c|}
\hline Source & SS & $d f$ & F $=0.81158$ \\
& 3214.7816 & 3 & 1071.5939 \\
\hline Between newspapers & 38291.0972 & 29 & 1320.3827 \\
\hline Within newspapers & 41505.8788 & 32 & & \\
\hline Total & & \\
\hline
\end{tabular}

The f-ratio value is 0.81158 . The $\mathrm{p}$-value is 0.497859 . The result is not significant at $\mathrm{p}<.05$.

Table 10. Directional analysis of farmers' suicide-related news items by selected newspapers

\begin{tabular}{|c|c|c|c|c|c|c|c|c|c|c|c|c|}
\hline \multirow[t]{2}{*}{$\begin{array}{l}\text { Subject } \\
\text { Categories }\end{array}$} & \multicolumn{3}{|c|}{ The Hindu } & \multicolumn{3}{|c|}{$\begin{array}{c}\text { The New Indian } \\
\text { Express }\end{array}$} & \multicolumn{3}{|c|}{ Eenadu } & \multicolumn{3}{|c|}{ Andhrajyothi } \\
\hline & $\mathrm{F}$ & Un & $\mathrm{Ne}$ & $\mathrm{F}$ & Un & $\mathrm{Ne}$ & $\mathrm{F}$ & Un & $\mathrm{Ne}$ & $\mathrm{F}$ & Un & ne \\
\hline Government & 24 & 20 & 2 & 3 & 2 & 3 & 23 & 3 & 6 & 24 & 3 & 2 \\
\hline Political parties & 5 & 28 & 2 & 2 & 8 & 1 & 12 & 14 & 3 & 7 & 6 & 2 \\
\hline $\begin{array}{l}\text { Administration } \\
\text { Revenue }\end{array}$ & - & - & - & - & - & - & - & - & - & - & - & - \\
\hline Police & 2 & - & 4 & - & 2 & 2 & 2 & 1 & - & - & 3 & - \\
\hline $\begin{array}{l}\text { Farmers/their } \\
\text { families }\end{array}$ & - & 10 & 3 & - & 3 & - & - & 16 & - & - & 2 & - \\
\hline Human rights & - & 6 & - & - & 3 & 1 & - & 9 & 4 & - & 1 & - \\
\hline $\begin{array}{l}\text { Protest by } \\
\text { farmers } \\
\text { associations }\end{array}$ & 2 & 9 & - & - & 2 & - & - & 5 & 2 & 2 & 6 & - \\
\hline Banks & - & - & - & - & 1 & 2 & - & 1 & 1 & - & - & - \\
\hline Media & - & 31 & 3 & - & 11 & - & 1 & 93 & 47 & 35 & 78 & 50 \\
\hline Others & 1 & 6 & - & - & 4 & - & - & - & - & - & - & 1 \\
\hline $\mathrm{n}=$ & 34 & 110 & 14 & 5 & 36 & 9 & 38 & 142 & 63 & 68 & 99 & 55 \\
\hline $\mathrm{N}=$ & \multicolumn{3}{|c|}{158} & \multicolumn{3}{|c|}{50} & \multicolumn{3}{|c|}{243} & \multicolumn{3}{|c|}{222} \\
\hline
\end{tabular}

Table-10 shows the direction of treatment given to the coverage of subject categories. The Eenadu reported number of stories on the theme 'Media' (93) unfavourably as compared to the Andhrajyothi (78). The Hindu and Andhrajyothi covered number of favourable (24each) news items on 'Government', followed by Eenadu (23). The English newspaper The Hindu covered more number of news items (28) on 'Political parties'. Similarly, the Telugu newspapers Eenadu covered more number of unfavourable news (16), as compared to The Hindu (10). The New 
Indian Express and Andhrajyothi (2). The Hindu gave more priority to the 'farmers' association protests' (9) unfavourably news.

Table 11. Directional analysis of farmers' suicide-related photos by selected newspapers

\begin{tabular}{|c|c|c|c|c|c|c|c|c|c|c|c|c|}
\hline \multirow[t]{2}{*}{$\begin{array}{l}\text { Subject } \\
\text { Categories }\end{array}$} & \multicolumn{3}{|c|}{ The Hindu } & \multicolumn{3}{|c|}{$\begin{array}{c}\text { The New Indian } \\
\text { Express }\end{array}$} & \multicolumn{3}{|c|}{ Eenadu } & \multicolumn{3}{|c|}{ Andhrajyothi } \\
\hline & $\mathrm{F}$ & $\mathrm{Un}$ & $\mathrm{Ne}$ & $\mathrm{F}$ & Un & $\mathrm{Ne}$ & $\mathrm{F}$ & Un & $\mathrm{Ne}$ & $\mathrm{F}$ & $\mathrm{Un}$ & ne \\
\hline Government & 6 & 6 & 2 & - & - & 2 & 6 & - & 6 & 9 & 1 & 2 \\
\hline Political parties & 2 & 9 & 2 & 1 & 3 & 1 & 6 & 6 & 1 & 3 & 3 & 2 \\
\hline $\begin{array}{l}\text { Administration } \\
\text { Revenue }\end{array}$ & - & - & - & - & - & - & - & - & - & - & - & - \\
\hline Police & 1 & - & - & - & - & - & - & - & - & - & - & - \\
\hline $\begin{array}{l}\text { Farmers/their } \\
\text { families }\end{array}$ & - & 4 & 1 & - & 1 & - & - & 12 & - & - & 1 & - \\
\hline Human rights & - & 1 & - & - & - & 1 & - & 2 & 4 & - & - & - \\
\hline $\begin{array}{l}\text { Protest by } \\
\text { farmers } \\
\text { associations }\end{array}$ & 1 & 4 & - & - & 1 & - & - & 1 & 2 & - & 2 & - \\
\hline Banks & - & - & - & - & - & 2 & - & - & 1 & - & - & - \\
\hline Media & - & 3 & 2 & - & - & - & - & 25 & 22 & 18 & 21 & 22 \\
\hline Others & - & 3 & - & - & 1 & - & - & - & - & - & - & 1 \\
\hline $\mathrm{n}=$ & 10 & 30 & 7 & 1 & 6 & 6 & 12 & 46 & 36 & 30 & 28 & 27 \\
\hline $\mathrm{N}=$ & \multicolumn{3}{|c|}{47} & \multicolumn{3}{|c|}{13} & \multicolumn{3}{|c|}{94} & \multicolumn{3}{|c|}{85} \\
\hline
\end{tabular}

The impact of the story in the news is more often determined by the photograph than the story itself. Because a photograph often affects a reader emotionally, more than words alone, pictorial evidence often have the weight on the established facts. For this reason, readers often get their first impression about a news story by looking at the photograph on the page. Thus, in the present study, the contents of photographs were analyzed to ascertain, how the newspapers had covered the farmers' suicides.

Out of a total of 239 photos, the highest number of photographs appeared in Eenadu (94) while Andhrajyothi (85), The Hindu (47) and The New Indian Express (13) came in the descending order. Interestingly, near half of the photographs in all the dailies were occupied with the theme 'Media' (113). As regards the theme 'Government' and 'Political parties' received 40 and 39 photographs respectively. The Telugu newspaper Eenadu initiates to write some stories about farmer suicides.

In the process, Eenadu published 25 unfavourable photographs and 22 neutral photographs. Similarly, Andhrajyothi published 21 unfavourable photographs to the 'Media' subject category. In the same manner, Andhrajyothi published 18 photographs favourable and 22 neutral. In these findings, the Andhrajyothi did not take any side.

Andhrajyothi published more number (9) of favourable photographs to the 'Government' subject category. Eenadu and The Hindu published 6 each photograph to the subject theme. Whereas The Hindu covered more number (9) unfavourable photograph to the 'Political parties'. These photographs are strongly criticizing the Government attitude towards farmers' suicides. The Telugu newspaper Eenadu published more number (12) unfavourable photographs on the theme 'Farmers and their family's agony'. This also highlights the Government policy failures.

In this research, the researchers find out the more number of stamp size photographs published by 'Media' theme. The newspaper expressed much interest to publish positive coverage to the 'Government'. In recent days the Agriculturally related stories appear mostly under crime news. Other than crime news Agriculturally related news was unimpressive and less interesting.

\section{Findings}

1. The two Telugu newspapers Eenadu and Andhrajyothi covered more number of news items than two English newspapers.

2. The English newspaper The New Indian Express did not give much importance to the farmer suicide issues. 
3. All four selected newspapers showed much interest to publish news and photos.

4. Very less number of news items published in editorial page of all selected dailies.

5. Majority of news items were published on inside page of all four newspapers. The Hindu published more number of news items are front page comparatively than other three newspapers.

6. A maximum number of the news item was received from the regional level. But space allocation The Hindu, The New Indian Express and Andhrajyothi allocated more space to national level news. But Eenadu gave much space to regional news.

7. Low priority was shown to 'agony of farmers/families' and 'protest by farmer associations'. Therefore, it was observed that these issues needed to be covered to some extent for the betterment of coverage.

8. Four selected dailies published more number of unfavourable news items to the farmer suicides. It shows on negativeness on Government steps and policies.

\section{Conclusion}

Causes for suicides deaths like adverse, rainfall, inconsistent prices, the rise in the cost of cultivation, had the position of co-operative credit agencies and commercial banks, showing the power of the money lenders and traders. Most of the farmers have invested heavily on digging and deepening of wells. In this study, 12 deceased farmers come under this cause of death. Especially, when all most all of the deceased farmers belong to the small and marginal farmers category. Agricultural money lenders generally charge 15 percent to 20 percent higher price to the nominal price. Such kind of tie-up with pesticides dealers who also supply seeds normally of low quality is lightening noose around the farmers' necks. The commission agents, the second major source of credit to the farmers also exploit them through the output linkage system and they received a fixed amount of commission on the sales of farm produce and so in order to assure their business as they start advancing amounts to the client farmers. The rate of interest charged is 24 percent and when payments are deferred the commission rate exceeds the normal two percent by another three percent. The other major problem is tenancy these are not qualified to receive any institutional credits.

The study of two each of India's highest circulated English and Telugu dailies finds that they devote only a minuscule proportion of their total coverage to farmer suicides issues. Even these low frequencies could be misleading because most farmer suicides news is not about the farmers/their families' agony and anxieties. The content analysis of 673 news items shows that about $50 \%$ of the coverage from 'media', $17 \%$ by 'Governments', $13 \%$ by 'Political parties' less than $10 \%$ is about 'suicides farmers families' and 'protest by farmers associations'.

From the above findings and discussion, it could be concluded the most of the farmer suicides were published in inside pages but front and editorial pages do not consist of less number of farmer suicides issues in the selected newspapers. The result showed similarity with the findings of the previous reviews of research studies.

\section{Recommendations for Media}

While reporting farmers' suicide the journalist should do a proper investigation and take experts opinion rather than just by going through FIR. Media should provide news which encouragers forming profession among educated youth. Media to conduct more interviews with those who attempt suicide and not only with the relatives and families of deceased farmers.

\section{References}

[1]. Angeliki Balayannis \& Brian Robert Cook. (2015). Suicide at a Distance: The Paradox of Knowing SelfDestruction. Progress in Human Geography, 1-16, doi: 10.1177/0309132515587469

[2]. Behere, P.B., \& Behere A.P. (2008). Farmers' Suicide in Vidarbha Region of Maharashtra State: A Myth or Reality? Indian Journal of Psychiatry, 50(2), 124-127.

[3]. Cantor, C.H \& Baume, P.J.M (1998): Access to methods of suicides: what impact? Australian and Newziland journal of Psychiatry. Tylor \& Francis online. 32(1). Pp8-14.

[4]. CHRGJ, (2011). Every Thirty Minutes: Farmer Suicides, Human Rights, and the Agrarian Crisis in India. Center for Human Rights and Global Justice. New York: NY School of Law.

[5]. Dandekar, et al. (2005). Cause of farmer suicides in Maharastra: An enquiry. Final report submitted to the Mumbai High Court. Tuljapur: Tata Institute of Social Sciences.

[6]. Deshmukh, Neelima. (2010). Cotton Growers: Experience from Vidarbha. In agrarian crisis and farmer suicides Vol.12. Land reforms in India, edited by R.S.Deshpande, 175-191. Delhi, London: SAGE.

[7]. Dongre, Amol.R. \& Pradeep R. Deshmukh. (2012). Farmers' suicides in Vidarbha region of Maharastra, India: A qualitative exploration of their causes. Journal of Injury and Violence Research 4(1): 2-6. 
[8]. Guha, Jennifer. (2012). 'Farmers suicides in Maharastra, India: Facts, factors, and possible fixes'. Honours scholar theses paper 235. Accessed by May 20,2015. http://digital commons.uconn.edu/srhonors_theses/235.

[9]. Jeromi, P. D. (2007, August 04). Farmers' Indebtedness and Suicides: Impact of Agricultural Trade Liberalization in Kerala. Economic and Political Weekly,42, 31, 3241-3247.

[10]. Kale, N.M., D.M. Mankar, \& P.P. Wankhade, (2014). Factors Affecting the Agrarian Distress Proneness in Vidarbha.Global Journal of Science Frontier Research: D.Agriculture and Veterinary 14(10).

[11]. Kale, N.M., D.M. Mankar, \& P.P. Wankhade, (2015). Impact of Government Packages on Livelihood Sources of Suicide Prone Farmers 'Families. Karnataka Journal of Agricultural Science. 28(1): 63-66.

[12]. Madhu Babu.J. (2010).Newspapers and Naxalite movement. New Delhi, Kanishka publishers:38-39.

[13]. Martin, Max \& Seema Kakde. (2006). Farmers' suicides in Maharastra -I: The Killing Fields of Cotton. In From Debt Trap to Death Trap. Victims of 'Free'Market - Enquiry into Farmers' Suicide, Edited by Max Martin \& Seema Kakde, 86-98. Mumbai: Vikas Adhyayan Kendra.

[14]. Meeta \& Rajivlochan (2006). Farmers' Suicide: Facts \& Possible Policy Interventions. Pune: Yashwantrao Chavan Academy of Development Administration.

[15]. Mishra Srijit. (2007). Risks, Farmers' Suicides and Agrarian Crisis in India: Is There a Way Out?Indian Journal of Agricultural Economics 63(1), 38-54.

[16]. Mishra Srijit. (2014).Farmers' Suicides in India, 1995-2012: Measurement and Interpretation. Asian Research Center Working Paper 62.

[17]. Mitra, Siddharta \& Sangeeta Shroff (2007). Farmers' Suicides in Maharastra. Economic \& Political Weekly. 42(49): 73-77.

[18]. Mohanty, Bibhuti.B. \& Sangeeta Shroff (2004). Farmers' Suicides in Maharastra. Economic \& Political Weekly. 39(52): 5599 -5606.

[19]. Mohanty Sachidananda, Geeta Sahu, Manoj Kumar Mohanty, \& Manju Patnaik,(2007).Suicide in India - A Four Year Retrospective Study. Journal of Forensic and legal medicine 14: 185-189. doi:10.1016/j.jcfm.2006.05.007.

[20]. Nagaraj K. (2008). Farmers' suicides in India: Magnitudes, trends and spatial patterns. Bharathi Pusthakalayam.

[21]. Niederkrotenthalera, T. \& Sonneck, G, (2007): Assessing the impact of media guidelines for reporting on suicides in Austria: Interrupted time series analysis. Australian and Newziland. Journal of Psychiatry.Tylor \& Francis online. 41(5).pp 419-428.

[22]. Patel Vikram, et al. (2012). Suicide Mortality in India: A Nationally Representative Survey. Lancet(379): 23432351.

[23]. Pool, S.I. (1966). Communications and Development. Myron Weiner (Ed.), In Modernization: The Dynamics of Growth. New York: Basic Books.

[24]. Radhakrishnan, Rajiv \&Chittaranjan Andrade. (2012). Suicide: An Indian Perspective.Indian Journal of Psychiatry, 54(4), 304-319.

[25]. Sainath, P. (2007 November 12). "Farm Suicides Rising, most Intense in 4 States", The Hindu, http://www.hindu.com/2007/11/12/stories/2007111253911100.htm.

[26]. Sainath P. (2007). The farm crisis: why have over one lakh farmers' killed themselves in the past decade?

[27]. Sarah Hebous, \& Stefan Klonner. (2014). Economic Distress and Farmer Suicides in India: An econometric investigation. AWI Discussion Paper Series No. 565. The University of Heidelberg. Dept. of Economics.

[28]. Shiva Vandana. (2004). the suicide economy of corporate globalization. $\mathrm{Z}$ net, 1-3. https://www.countercurrents.org/glo-shiva050404.htm.

[29]. Shroff, Sangeeta. (2006). Cotton Sector in Maharashtra. In Suicide of Farmers' in Maharashtra (Submitted to the Government of Maharashtra), edited by Mishra, Srijit, Sangeeta Shroff et al., 25-44, Mumbai: Indira Gandhi Institute of Development Research.

[30]. Sridhar, V (2006). Why do farmers commit suicide? The case of Andhra Pradesh. Economic and Political Weekly. April, 22. 